\title{
ANT and Politics: Working in and on the World
}

\author{
John Law • Vicky Singleton \\ Published online: 18 October 2013 \\ (C) Springer Science+Business Media New York 2013
}

\begin{abstract}
While it is possible to define ANT in a series of abstract bullet points to do so is to miss most of the point. Instead it explores and theorises the world through rich case studies. This means that, like symbolic interactionism, for ANT words are never enough: you need to practice it. In this paper we work empirically, drawing on an ANT-inflected ethnography of Norwegian salmon farming, and also dialogically. We do this because we want to show that for ANT theory is created, recreated, explored and tinkered with in particular research practices. Indeed, ANT is probably best understood as a sensibility, a set of empirical interferences in the world, a worldly practice, or a lively craft that cherishes the slow processes of knowing rather than immediately seeking results or closure. In particular it is sensible to materiality, relationality, heterogeneity, and process. At its best it understands itself as working in the world to create analytical contexts; but also on the world, to articulate and press particular contexts and their politics. As a part of this it explores the contingencies of power, generating tools to undo the inevitability of that power, while working on the assumption that other and better worlds are possible.
\end{abstract}

Keywords Actor-network theory $\cdot$ Sensibility $\cdot$ Sociological craft $\cdot$ Materiality $\cdot$ Relationality Process $\cdot$ Politics $\cdot$ Feminism $\cdot$ Power $\cdot$ Ethnography

Actor-network theory (ANT) comes from Science, Technology and Society (STS), a discipline that is distinctive because it thinks theoretically through a rich tradition of qualitative case studies. This means that whilst it is possible to define ANT by using a series of abstract bullet points, attempts to do so miss most of the point. In this respect it is like symbolic interactionism (Rock 1979). For the argument made in the context of ANT, see Law (2008). Words are not enough. You need to practise

\footnotetext{
J. Law $(\bowtie)$

ESRC Centre for Research on Socio-Cultural Change (CRESC), Department of Sociology, Faculty of Social Sciences, The Open University, Walton Hall, Milton Keynes MK7 6AA, UK

e-mail: John.law@open.ac.uk

V. Singleton

Centre for Science Studies and Centre for Gender and Women's Studies, Department of Sociology, Lancaster University, Lancaster LA1 4YN, UK

e-mail: d.singleton@lancs.ac.uk
} 
it. For this reason, in what follows we work empirically, drawing on an ANT-inflected ethnography of Norwegian salmon farming. ${ }^{1}$ For related reasons we also work dialogically. We do this because in ANT theory is not reified, separate or abstract. It does not pre-exist, waiting to be applied. Instead it is created, recreated, explored and tinkered with in particular research practices. Perhaps, then, ANT is best understood as a sensibility, a set of empirical interferences in the world, a worldly practice or a craft. At any rate, our hope is that "talking" about it will help to make it lively.

Vicky: Where do you think this sensibility comes from?

John: How about Thomas Kuhn's Structure of Scientific Revolutions? ${ }^{2}$

Vicky: Kuhn didn't do actor-network theory.

John: No. But STS started in at the end of the 1960s when sociologists read Kuhn, and realized that science is a kind of craftwork. In science you learn "theory" but as a part of this you also learn a way of living and being. Practices carry science: gestures, manual craft skills, instruments, and an educated eye. Scientists see and sense their worlds in particular ways. It seems to me that STS learned this from Kuhn and then went on to work in this way itself. This is why grand theory and STS don't mix well. Vicky: Fine. But it also drew on feminism.

John: How so?

Vicky: In two ways at least. You've just said that knowing is embodied, situated, and embedded in practices, and practices are always being done somewhere. So when it works well ANT is located. There's no grand overview, no neutral place. ${ }^{3}$ I think those of us who do ANT learned this from feminism, or at least became more aware of it through feminism. And, for me, ANT is informed by something else too: the idea that knowing is an intervention in the world. To know is to make a difference. The only question is: What kind of an intervention? What kind of difference? I think an ANT sensibility learned this from feminist technoscience studies as well.

John: So the underlying point is quite radical, isn't it? In effect you're saying that science and social science don't represent reality neutrally. You're saying that we work in the world, but also that we work on the world. And, as the anthropologist Tim Ingold puts it, we're alive to the world too. ${ }^{4}$

Vicky: Yes. Exactly that. Academic work is performative. It is always an intervention. It's just that often the intervention may be invisible, denied or unacknowledged. And, the difference it makes will always be unknowable in its entirety.

\footnotetext{
${ }^{1}$ This project, "Newcomers to the Farm," has been funded by Forskningsrådet, the Norwegian Research Council (project number 183352/S30), with additional research leave and financial support from Lancaster University, the Open University, and the University of Oslo. It has involved a long-term collaboration between John Law anthropologists Marianne Lien and Gro Ween, and historian Kristin Asdal. All three are at the University of Oslo. For the project website please visit: http://www.sv.uio.no/sai/english/research/projects/ newcomers/. We are deeply grateful to Marianne for allowing us to use materials from the project, and also, and in particular, for the chance to work intensively and extensively in the interdisciplinary space between STS and social anthropology. We are also grateful to the anonymized "Sjølaks AS" for their kind agreement to let us locate this study within their firm, and for its additional generous practical support. We would like to thank all those who work for Sjølaks (they too are anonymized) for their warm welcome, help, and willingness to let us watch them at work. In many cases their kindness vastly exceeded any reasonable expectation or need. Finally we are grateful to our colleagues within and beyond ANT for continuing support and talk, and to the editors of this special issue of Qualitative Sociology for their feedback on an earlier version of this paper.

${ }^{2}$ Kuhn (1970).

${ }^{3}$ On situated knowledges, see Haraway (1991), and in the context of STS, Haraway (1996).

${ }^{4}$ See, for instance, Ingold (2011).
} 


\section{An Hour in the Sun}

On the fjord it rains. Sometimes it snows. Sometimes it blows like all hell. Sometimes it is very, very, cold. But then again, sometimes it is warm, sunny and calm. Right now it is June and John is out on the fjord on the fish farm: ${ }^{5}$

The site is stunning. It's under a steep tree-covered peninsula. The trees are mostly pine, some deciduous, and there are small crags and rocks. It's a nature reserve high up, says [co-worker] Freddy. People are not allowed to walk there. Eagles nest on it.

There are mountains all around, and in the distance you can see the glacier. And this is the fieldwork site. There are eight round fish pens, with around 650,000 salmon in all. In due course they will be slaughtered, and will end up being sold to Japan, the Middle East, or Europe.

It's about four in the afternoon. We've all been working hard. But suddenly there's a shout from the boss. Everyone stops. There's going to be a wait. Most of the people go back to the common room on the boat. This leaves three of us on the two-foot wide walkway running round the pen. We are just six inches above the water. Field notes:

There's ... nowhere to sit on these rings, except the walkway. Freddy and I sat down, and then I felt very [sleepy and] tired. I lay down on the rather narrow space of the grille of the walkway, pulled my cap over my eyes, and asked him to wake me up shortly before I fell in the water. And I nearly went to sleep - though I didn't because I thought it would be disorienting to wake up in such a place. When I came round and sat up, Freddy was looking at the water - there were tiny baby shrimp. We chatted about this and that ... And then, finally, I guess nearly an hour had passed, and the [boat] tender came back.

The field notes don't mention that it was calm - the sea was like glass. And neither do they mention that it was very, very hot.

\section{Slow Research—and Staying with the Trouble}

Vicky: It sounds beautiful. But tell us what's important about this ethnographic moment to this conversation.

John: I'm curious about the idea of working in and working on the world. I'm concerned that people might think that we are relativists.

Vicky: If that's a danger, then we need to be clear. We're not relativists. That's not what ANT is about at all.

John: I agree. But let's approach the topic obliquely. You once told me that "research should be fun." At the time I was startled. I'd always thought of research as serious. I'd like to ask you why you said that.

Vicky: Because I believe it! Of course research can't be fun all the time, but I'm certainly fed up with research treadmills!

John: Yes!

\footnotetext{
${ }^{5}$ In the project John Law and Marianne Lien usually did joint fieldwork, sharing field notes, discussing these, and sometimes combining them. Usually, however, within the fieldwork site they would work in different locations. Most of the field notes on which this paper is based were originally written by John.
} 
Vicky: I guess the salmon ethnography was fun in parts. I certainly hope so. So that's a part of it. But I was also thinking that research should be fun because good research is passionate. And also because it is slow. Or at least it should be.

John: Slow? Like slow food?

Vicky: Why not? Why not take pleasure in the process of doing it? After all, it is a process. And why not take pleasure in being led? Slow is not just about time. ${ }^{6}$

John: Being led?

Vicky: Yes. Slow research is research that doesn't always take the lead. Instead it often follows. In woodwork you sense the grain of the wood. Craft research is shaped by the patterns of interaction and practice that it's immersed in. You don't assume too much. You let the research unfold. You do care-full research.

John: Care-full research?

Vicky: Yes. STS literatures on care, for instance in medicine, talk about tinkering slowly, experimentally and collaboratively to find the best way forward. ${ }^{7}$ Think of diabetes. This is a condition that can only be managed up to a point. ${ }^{8}$ It seems to me that slow research would be care-like research. It would unfold uncertainly. It would be sensitive to ethnographic surprises. It wouldn't be highly programmed.

John: "Sensitive to ethnographic surprises." That's the working in the world isn't it? If you work in the world then your practice is shaped by the world. It may bite back. It's about "becoming with" the world. So what you're doing isn't relativist. It's not a matter of "anything goes." It's more like a bumpy process of experimenting. Of laying your research open to the uncertainties of the world.

Vicky: That's what I would like ANT to be, a set of care-full empirical and theoretical sensibilities. And it's why I worry when ANT gets turned into bullet points in textbooks. Those sensibilities get lost.

John: But there's something more too. Politics. We've often been criticized for doing research without knowing why, politically. We've been told that good research is research that makes a difference. Indeed, a moment ago you said just that. So it can't just be a matter of being empirical and experimental and waiting to see what turns up. Not that alone.

Vicky: That's right. The politics - it's always there — is about working on the world. That's why I think that good research is also passionate or engaged. It doesn't freewheel. It isn't just empirical — or simply clever. Instead, as Donna Haraway puts it, it works by "staying with the trouble" even if it disrupts boundaries and assumptions; ${ }^{9}$ or precisely because it does this. And it may do so in ways that don't follow obvious political agendas.

John: So good research is passionate because it is disturbing.

Vicky: That's right; that's what attracted me to ANT in the first place.

\footnotetext{
${ }^{6}$ Recent ethnographic and STS work has inspired this interest in "slow research." For example, Tim Ingold (2011) argues that the current academic environment "is profoundly hostile" to the kinds of engagement that are required to understand; what he calls work that is alive to the world, and is not only done in the world. He makes a plea for observant engagement through moving, knowing and describing. This suggests the researcher is "becoming with" the research environment over time. Jean Lave (2011) describes her very lengthy and sustained engagement with a research environment as an apprenticeship in critical ethnographic practice that facilitated ideas outside the dominant ethnographic paradigm. Bruno Latour $(2010,487)$ makes a plea for slowing down in his compositional manifesto as generative of critique. And Isabelle Stengers (2011) suggests that "slow science" is a mode of resisting dominant, damaging framings of science and of enacting alternative realities.

${ }^{7}$ Mol et al. (2010).

${ }^{8} \mathrm{Mol}(2008)$.

${ }^{9}$ Haraway (2010).
} 
Perhaps, then, ANT is best treated as sensibility, as a craft or a set of practices that works slowly both on and in the world, as uncertain, as empirically sensitive, as situated, and as passionate because it stays with the trouble. So it was for John in the fieldwork on the fjord, at least some of the time. He became part of a world of practices: the heat, the landscape, the temporalities, the authority of a boss, the techniques and technologies, the actions of salmon, the friendships with co-workers. Fieldwork was a sensibility. Like ANT.

\section{Oxygen and Deltamethrin}

Freddy and I were tired. It was hot but we'd been working hard. We'd been helping to delouse the salmon.

Here's the problem. Salmon attract parasitic sea-lice that attach to, feed off, and breed on them. In large numbers such sea-lice hurt the fish, and since suffering fish grow poorly and attract adverse publicity they aren't good for salmon farmers either. And sea-lice are a particular problem on the farm because there are so many fish close together. So farmers try to control them (Revie et al. 2009).

In the most elegant solution small fish-various kinds of wrasse-live in the pens with the salmon. The Norwegians call these "leppefisk" or "lip fish." They eat the sea-lice off the salmon. Biological control (Deady et al. 1995; Amundsen et al. 2010). But the farmers also use chemicals (though these are becoming less effective), and that is what we were doing on that sunny June day. We were pouring a treatment based on the insecticide deltamethrin into the pens to kill the sea-lice. But you can't just pour the chemical into the sea; it would simply disperse. So first you pull the nets most of the way in so the salmon are close to the surface. Then you protect the pen from currents flowing in the water. And finally you finish pulling the nets all the way in (You do this in two stages so you don't stress the salmon too much. They don't like being crowded together near the surface). Only then can you douse the salmon in deltamethrin.

But pulling in the nets:

is grueling work. Three or four men are leaning over the rail into the pen and pulling as hard as they can on the net, lifting on it with claw-like hooks on a little plastic ring...The netting is extremely heavy, and it's also slimy. This is a job that does his back in, says Freddy.

Cutting off the currents involves draping a tarpaulin all the way round the outside of the ring. This hangs like a skirt down into the water to below the level of the net. To do this takes five or six men and the crane on the tender:

This is extremely hard work, partly because of the sheer weight of the tarpaulin, and partly because it has to be threaded beneath the anchor cables... The tendency of the tarpaulin is to get itself snagged, and it has to be endlessly teased through or under these, by people on their hands and knees, up to their elbows in water, or... artfully using boathooks. There's always the risk of tearing it, though this is more likely when the crane is doing the pulling.

We're part way through the third stage — pulling the net all the way in — when the field notes start to talk about oxygen levels. Kristoffer, he's in charge, has been measuring these all day. He's been slinging an oxygen sensor on a cable into the pens and checking the readings on a hand-held monitor. In the first pen in the morning the figure was $85 \%$. No problem. In the second it was $60 \%+$. This was pretty low, and Kristoffer told the skipper of the tender boat to lift a corner of the skirt to let in fresh water. Stressing salmon is a bad idea. They suffer, they may die, and they stop growing. But now it is afternoon, we are on the third pen, the reading is between $55 \%$ and $60 \%$, and it is obvious 
that the fish are stressed. They are breaking the surface of the water with their dorsal fins and their mouths: It is almost as if they are trying to breathe the air.

[T] hey couldn't do the treatment with oxygen levels as low as these. Would Kristoffer call the whole thing off?... We waited while Kristoffer and Peter ran around taking readings... Then Kristoffer made the decision. We had oxygen in one of the supply boats, but we didn't have the pipes needed to diffuse it into the water. So he sent Einar off in one of the boats to get them. A long journey, because he had to go to [the next fish farm] and back.

This was the moment when Freddy and John lay down on the walkway in the sun.

\section{ANT as Sensibility-How Actors Grow in Heterogeneous Webs of Relations}

John: We've said that ANT is a sensibility and that it is a form of craft-work that is empirically sensitive. I hope that we can see this here because: first, this is a story that describes the heterogeneity of the world; second, its relationality; and third, it reflects the way in which it is unfolding and uncertain.

Vicky: Let's start with heterogeneity.

John: It's quite simple. What's going on involves materials of different kinds. There are people like Kristoffer. There are technologies like oxygen meters, boats, and nets. There are inscriptions and texts such as readings for oxygen levels. And of course there are animals like salmon and sea-lice.

Vicky: So as the jargon puts it we have a list of "actors," human and non-human; documents, devices, and drilled people. ${ }^{10}$ Not to forget animals. We need to discuss what we mean by an "actor." But first, what about relationality?

John: Again it is simple. Everything is entangled with everything else. They are all interrelated. Nets and people and tarpaulins and boathooks and oxygen meters and oxygen levels and salmon and oxygen supplies and boats and pipes, all of these are woven together. Together they form a network.

Vicky: Or a web. Or a meshwork. ${ }^{11}$ Or a cat's cradle. ${ }^{12}$

John: Yes: A web of relations; an actor-web; or an actor-network; or a rhizome. The metaphor doesn't need to be pinned down and fixed. What's important is that the relations also define or characterize the "actors" caught up in that unfolding web. The shape they take depends on all the webby relations. And this explains the third move too: the unfolding and uncertain character of the world. Because if the web holds steady, so do the "actors" in it. While if it shifts, and mostly it does, then so too do those actors. Oxygen levels fall as the water stops circulating. Healthy salmon become stressed and in extremis they die (not that this happened here). Cheerful managers get anxious. Workers get tired. Things are put on hold. Distant oxygen supply pipes are collected, connected to oxygen bottles, and oxygen saturation levels rise. In principle everything is uncertain. There are no guarantees.

Vicky: There's a lot to take in here. Let's go back to the "actors." We need to remember that some people don't like ANT because it says objects are pretty much like humans; that they are actors too. And vice versa. For some people this sounds uncaring. Inhumane. But I think this is a bit of a misunderstanding. ANT isn't saying that people are robots. It's

\footnotetext{
${ }^{10}$ The phrase come from Law (1986).

${ }^{11}$ Ingold (2011)

12 The metaphor is explored by Haraway (1994).
} 
saying that people can be understood as an effect of the unfolding web of relations they're caught up in. And that human and non-human actors are assembled together.

John: And as Bruno Latour puts it, it is saying that we need to "follow the actors" to find out how they are shaped by those assembled relations. ${ }^{13}$

Vicky: At the same time, an actor is something that acts. Makes a difference. Is therefore detectable in the scene. Again that's what Bruno Latour suggests. ${ }^{14}$

John: That's how I try to work in practice. It's what I was trying to do on the fish farm. The oxygen acts - it calms the fish. The fish act - they lead the people to go looking for oxygen. And the people are acting too, of course. They stop what they are doing and go off looking for oxygen. It's a kind of dance, a form of choreography. ${ }^{15}$ Everything is related to everything else. And gets itself assembled, one way or another. Vicky: But, as Tim Ingold tells us, it's also a methodological sensibility to do with working in the world and being sensitive to the world. ${ }^{16}$ If you can put your preconceptions about the character of actors on one side, then you start to learn how scenes - and the actors in the scenes - get assembled in practices and the relations being done in those practices between whatever is being muddled together. How people become human in particular ways. Or animals take the form they do. ${ }^{17}$

John: "How," that's the crucial world. For me, an ANT sensibility isn't saying that people (or salmon or technologies) don't exist. Obviously they do. But it's interested in exploring how they get put together in practices - and how they get distinguished from one another.

Perhaps, then, ANT isn't a theory. Perhaps it is better thought of as a sensibility to the materiality, relationality and uncertainty of practices, as a way of asking how it is that people and animals and objects get assembled in those practices, and as a way of mapping the relations of practice. Perhaps this is how it works in the world. But what about performativity? What about working on the world?

\section{Counting Sea-Lice}

Knut and Frederik are...netting...salmon (these are attracted with a scoop-full of feed.) Then they [the salmon] are plonked in a container of water-about the size of a washing tub...There is anaesthetic in the water (not too much, or it kills them). Knut holds the net over the basin while the salmon that he's just caught...thrash around. Otherwise they are liable to leap out (this happens from time to time). Then once they've calmed down he or Frederik lift them up by the tail... and look carefully for lice...Some [of which] I find difficult to see...Once they're counted (there were between zero and five on the salmon they looked at)...the salmon get tossed back in.

Marianne and John are on another fish farm a couple of miles down the fjord-but the routine is similar everywhere. Every fortnight someone like Knut goes round the pens. The notes don't say this, but it's quite hard to catch four- or five-kilo salmon with a long-handled net - and strenuous too. But it has to be done. Twenty fish have to be caught, hauled out of the pen, anaesthetized, and checked for lice. The lice count is recorded by pencil on

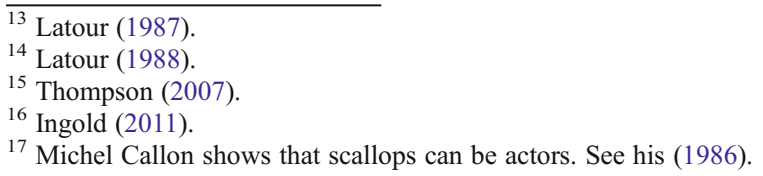


waterproof paper (it gets pretty wet out there even when the sun is shining). Then the figures are taken back to the control room and keyed into the computer, and they're sent off by broadband to head office.

Lice counts are important. The firm watches them, and so too does the Mattilsynet, the Norwegian Food Safety Authority (Mattilsynet: Norwegian Food Safety Authority 2012a). Lice, we've said this already, are bad for fish but also bad for the balance sheet. They are also (we'll come to this in a moment), bad for wild salmon too. And there are limits on the permissible number of lice: For most of the year this is 0.5 mature female lice per salmon, plus three immature lice (it's slightly higher in the late autumn and early winter) (Mattilsynet: Norwegian Food Safety Authority 2012b). These are the figures Frederik and Knut are helping to compile. Eleven pens on the farm, twenty fish per pen, 220 fish are being sampled every two weeks. If the count rises above the official limit then delousing is mandatory.

All farmers must regularly count and calculate how many lice there are in the farm. If there are too many lice, then the farmer must delouse within 14 days. If the treatment is not successful, the farmer must immediately use a second agent or kill the fish. The Mattilsynet Authority may if necessary require slaughter. ${ }^{18}$

That's the Mattilsynet web site. Mattilsynet vets may visit the farm and the farm's own vets have to report issues to the Mattilsynet.

[T] he vet sits down at the big table, and chats with Frederik for a while.... [She is there to discuss a different topic] but [h] e prints out other things upon her request, luseskjema (the lice report)...there is clearly a problem with lice in [pen] $11 \ldots[\mathrm{He}]$ says they were supposed to do...delousing but were allowed by Mattilsynet...to postpone it a little...to see whether the leppefisk [the wrasse] might do the job...Frederik is glad he can wait... he doesn't want to stress the...[salmon] too much... The vet has no objections...but she recommends that he from now on does the lice counting once a week, and not every fortnight as they have done until now.

\section{Ethnography: Working in and on the World-Context, Scale and Power}

Vicky: So what's important about this ethnographic snippet?

John: It's on lice and delousing; and it's also about the larger context. The Mattilsynet and the veterinary service, not to mention broadband and anaesthetic.

Vicky: But you've already talked about the "larger context." We've heard about deltamethrin, oxygen meters, boats, nets, and devices for lifting nets. All of these imply larger contexts. Surely ethnography is always about contexts.

John: Yes. That's right. If you "follow the actors" they lead us into contexts. Sociologists sometimes distinguish between what's happening here and now and its context, but the distinction doesn't hold up very well.

Vicky: So it really isn't stupid to say that the whole world is there on the fish farm if you go looking for it. ${ }^{19}$

John: That's right.

18 English translation from Mattilsynet: Norwegian Food Safety Authority (2012b) (accessed 23 July 2012).

19 ANT can be understood as philosophically monadological. See Latour (1988) and Law (2004). 
Vicky: And this is an essential part of the ANT sensibility. If you look for relations and materials and processes then they spread out everywhere. And it was always like that. Even before globalization.

John: Yes. So on the fish farm it is salmon all the way down. And people and government agencies and economic markets, and fish science and welfare concerns and local communities and feed and feedstock fish from Chile and big pharma, and food markets and chilled distribution chains and consumers.

Vicky: In one way there isn't much distinction between the "micro" and the "macro" in ANT. Or perhaps it would be better to say that the macro is inside the micro. The Chilean feedstock industry is inside the feed pellets. Which means that in one way the "macro" isn't necessarily bigger than the things that happen on the farm.

John: Or you could say that the macro becomes macro only to the extent that it is done as macro, down on the farm. Mattilsynet's rules and regulations - and Mattilsynet itself-become "macro-actors" because they are treated as powerful by Frederik, Knut, the vet, and everyone else on the farm.

Vicky: Okay. But perhaps we should pause for a moment and talk about what we mean by power. We haven't actually said what it is.

John: For me it's something like this. When sociologists talk about power they usually think of power as a kind of domination. One group dominates another. Constrains or exploits it. Perhaps we could think of this as "power over." So, for instance, Kristoffer in some small way has power over the people doing the delousing out on the fjord.

Vicky: Or the people or the firm have power over the salmon in the pens.

John: Agreed. But there's another understanding of power, as in a phrase like, "electric power," or "put on the power."

Vicky: In what kind of context?

John: Oh, I'm not trying to be clever here. I'm thinking of fiddling with the fuse box, putting the fuse back in, when you're looking at the wiring in your house.

Vicky: Right. So your point is?

John: If we think about this, then we are talking about the power to do things; the power to act.

Vicky: Okay. And ANT is interested in both: "power over," and "power to." But it sets off in the first instance by thinking about the power to do things, the "power to" that grows out of the webby relations and practices.

John: Yes. Like an electric circuit, though that's a very mechanical example.

Vicky: So presumably you would want to say that the "power to" farm fish depends on the network of actors that make up the fish farm.

John: Yes. All the webs that make it up. But I'd also like to say that "power to" isn't necessarily a zero sum game.

Vicky: Meaning?

John: Well "power over" necessarily has winners and losers. When the salmon get slaughtered they lose their lives, and the firm makes a profit. If the boss of the firm cuts the wages (not that he did) then he's the winner and the people who work on the farm are losers.

Vicky: Okay. But you said that "power to" isn't necessarily a zero-sum game.

John: Yes. And that's because the networks of webby relations and practices that make up an institution like a salmon farm mean that the overall power to do things, the power to act, is increased. 
Vicky: What do you mean, the "overall power to do things?"

John: Relations are enabling. Not equally. Sometimes exploitatively. That's the "power over" but. But alongside the power over, or before it, relations weave actors with abilities or capacities that they wouldn't otherwise have had. That's what I mean. Vicky: So ANT assumes that power is "social." It's about association. You can't farm fish on an industrial scale without people working on the farms. You can't do it without the help of vets and accountants. You can't do it without buying fish feed, and you can't buy fish feed without the efforts of the Chilean feedstock industry and the global lines of trade and credit that connect you to that industry. Or, for that matter, the efforts of the feedstock species in the Pacific to reproduce themselves. The "power to" farm salmon on a large scale is a consequence of all these practices, and the business of pulling them together in a particular way.

John: Exactly. "Power to" do things grows out of lots and lots of interwoven practices. ${ }^{20}$ And it's all a bit of a juggling act, holding all those practices together, because practices work in different ways. The life cycles of salmon, the demands of markets, and the requirements for environmental protection don't go together "naturally." So the power to do things is always a bit uncertain. It may all fall apart. In the salmon industry. Actually in life. Anywhere.

Vicky: So the actor-network sensibility starts out by thinking about how the "power to" do things is achieved by patching practices together. And then it asks about "power over." About how all those interwoven practices also distribute power unevenly, in the more usual sociological sense. So that women are excluded from some kinds of jobs on the farm. Or that the Mattilsynet has power over the salmon farmers in certain circumstances.

John: Yes. But this raises a question: how does articulating or recognizing either version of power make any kind of difference?

Vicky: An interesting question. You don't need to know much about the fishing practices in the Pacific if you're a fish farmer. All you need is the feed, at a reasonable price. All those practices just go on anyway. You scarcely need to recognize it. It just goes on anyway. It's part of the pattern of relations and practices. In fact, you can't articulate most of the webby practices, or the power that they are doing. They ramify off in every direction and go on forever. You have to be selective. You have no choice. In ANT and in life too! John: So here's a question. How do they get recognized? Sometimes? And what happens when they do?

Vicky: I don't think ANT has really thought this through. Not entirely. I think that this is one of the reasons it's been challenged by feminism.

John: Agreed.

Vicky: So, let's see. We need to start from the assumption that both kinds of power, "power to" and "power over" are being endlessly done in the webs of practice. Then we need to say that they sometimes get made explicit.

John: Yes. But when?

Vicky: Don't they get made explicit when they become problematic? When people need to attend to them?

John: Okay. So salmon farming is like life. There are always new problems to be solved. Here's a recent example. Animal scientists mostly now say that fish are

\footnotetext{
${ }^{20}$ ANT works with both power to, and power over. So it's close to Foucault. Indeed it probably learned about power from Foucault. Because when he talked about the "microphysics of power" he was talking about the patterning of associations - about implicit and explicit relational strategies which are powerful.
} 
sentient. That they can experience pain. This is a new development. Ten or 15 years ago that would have been a minority view. Anyway, this change is reflected in new Norwegian welfare regulations. For example, in Norway salmon have to be stunned electrically before they are slaughtered.

Vicky: I think you're saying two things. The "power to" farm and slaughter salmon depends on new stunning technologies. New practices. But if you're talking about slaughter and regulations then you're also talking about "power over." The power of the farmer over the fish, and the power of Mattilsynet over the fish farmers.

John: That's sounds right.

Vicky: But we still haven't got to the bottom of this. We said a moment ago that power becomes explicit when it is problematic. But we need to add that this may happen in two ways. The people we talk with in fieldwork may do it, our "respondents." And/or we may do it as we do that fieldwork or write about it after the event.

John: I've got an example of the latter. Gendering. No one talked very much about gender on the fish farm. But there were things about gender that struck Marianne and me. That jumped out at us.

Vicky: For instance?

John: By and large women don't work out in the middle of the fjord. It's not a rule. There are exceptions. Perhaps they're increasing in number. I don't know. But mostly that's the case right now. And then again the men we met were generally quiet, selfcontained, reserved, self-reliant. We noticed this most in the mornings when they gathered in the workshop amongst the tools and the benches. They nodded to one another and to us. They were courteous. But unless there was something practical to discuss most mornings they didn't talk much. Both of us found this interesting.

Vicky: So what's the point you're making?

John: What's problematic, or at least interesting, sometimes forces itself on you, given your own agendas. Or the contexts that are important to you. After all, ethnography is an embodied experience. But then you can "context" it in one way, or another.

Vicky: So, for instance, you can put gendering in the context of job distributions. Who gets to do what, and who doesn't. Or you could put it in a context of overt sexism.

John: In the UK in many male-dominated workplaces you would come across pin-ups in washrooms. And sexist comments. Which we didn't see on the farm. But then again, you can also choose to run with a topic, or not.

Vicky: Are you suggesting that gendering isn't interesting or important?

John: No. I hope it's clear that how maleness is done on the farm was very interesting. Vicky: So the point is more general. When we describe a scene we make choices - mostly implicit - about what we're going to describe and what we're going to leave out. About which actors to follow and which to leave be. About what to treat as powerful in either of the two ways we've just talked about, and what to ignore. And those choices partly depend on our own agendas, political, theoretical, personal. And they partly depend on how we're being led by our ethnography, on what people are saying. Their problems.

John: That's right. But I don't think there are any rules here. How should researchers relate to past research and theories? The answer, no doubt, is respectfully. But in the end we can't relate to everything. Some things get ignored. So, for instance, here I made a "decision" not to go into gendering and think about it as a form of power - in either sense.

Vicky: Why?

John: I suppose it was partly because I wasn't sure what I could add to the debates about gendering, and the "power over" that this does. And partly because I was thinking about another form of power and another kind of context. 
Vicky: Which was?

John: I wanted to think about how nature gets done. Because nature is powerful too. Though mostly we tend not to think about it that way.

Vicky: Okay. I share your interest in nature, and I can see why you might want to do that. But an interesting implication follows.

John: Yes?

Vicky: It's that a choice like this - any kind of choice-means that you're not attending to the full specificity of a field. So to translate into an ethnographic story is also to betray. That's what Michel Callon taught us. ${ }^{21}$

John: Yes. That's right. It's inevitable. To describe is always to simplify. It's to look for similarities as well as differences. This means that it's always a matter of trying to strike a balance. And of deciding what to simplify_ or ignore — and what to attend to. So the actornetwork sensibility to specificity is selective. I still think that we do "slow research" because we are interested in how things like power get done. This makes us slow. We work slowly. We open ourselves up to what's happening. We try to be responsive to it. But of course we're not slow about everything. That's not possible!

Vicky: Okay. So we've been thinking about how ANT research works in the world, but now we're shifting because we're thinking about how it works on the world. About the kinds of work, political and otherwise, that it does. About the contexts it creates, ${ }^{22}$ and the language it uses.

John: That's right.

Vicky: We've been saying that research is descriptive, but it's never simply descriptive.

John: And the language is important too. Marianne says that for ANT, language is like the elephant in the room. We don't talk about how we choose words. Their materiality. Or the work they do.

Vicky: I agree. That's another "choice" and no doubt something we need to think about. But let me say something different before we move on. Sometimes people say: ANT doesn't deal with the big structures of power because it doesn't attend much to class, or gender or ethnicity. In response I'd say, well yes, that's somewhat true, even though I can think of places where it isn't.

John: So what are you saying?

Vicky: First, that ANT is very interested in how power is done. But second, it is also suspicious of reductionist versions of power. Or particular versions of structure, the versions of structure that tend to be most important for social scientists. Obviously if we go looking for gendering we will discover it. It's important to do this. But an ANT sensibility is also a way of looking for unexpected forms of power and how these work. Unexpected kinds of structure. "Power to" and "power over;" these come in endless different forms, and we don't know very much about a whole lot of them.

\section{Villaks}

Today...we were tying up the safety ropes round the pen. They hang down from under the lip of the deck. You need to thread them through large plastic covered eyes in the nets themselves. To do this you need to sit or kneel on the deck, or even lie flat out...You can do

${ }^{21}$ Callon (1986).

${ }^{22}$ For discussion of contexting see Asdal and Moser (2012). 
it in gloves, but it is easier (almost everything is easier) to do it without. And then just beneath the feed pipes you find the rope and the deck have a small layers of powdered feed. Slightly damp. Slightly sticky. It clings to your fingers and to the cuffs and the sleeves of your overalls. You can rub some of it off your fingers, but it is still there, still slightly sticky.

The pens vary in size, but the small ones are 25 meters squared. The net round the pen hangs down into the water, held fast by wires, pegged to the handrails, but also tied in place by the safety ropes. What are the safety ropes for? I ask and the answer isn't very informative though it comes with a smile: "For safety." "Safety" meaning that the nets need to be really secure.

Back on land where they rear the smaller salmon in fresh water tanks, the wall that they were building in 2011 is finished now. Like a concrete motorway barrier it's nearly a meter high and runs all the way round the low end of the site and along the river. There are two or three places where water flows from the farm and I look at the multiple grilles it passes through. Nothing is being left to chance.

A few kilometers away at a much larger site, I watched as they hatch the eggs that become yolk-dependent alevins which in turn become tiny salmon fry. Ready to start eating for themselves for the first time, these are decanted, 50,000 a time, into two meter diameter tanks. A small number escape with the wastewater. At one moment in March 2010 I spent time with Ingrid in the corner of the building where they get stopped by the rotating water filter. We were trying to catch them with little nets to return them to the tanks. It made me think of fishing for minnows when I was a kid.

What's the context here? The answer is that domesticated salmon need to be kept in. This makes economic sense. A firm that loses its salmon goes out of business. But there are other pressures too. In particular, you need to keep the farmed salmon away from the "villaks," the wild salmon. Though the separation is never complete. More stories: "In Norway, 3.93 million Atlantic salmon...0.98 million rainbow trout...and 1.05 million Atlantic cod... escaped from 2001 to 2009" (Jensen et al. 2010, 71).

We're talking about a 2009 farmed Norwegian population of around 310 million salmon and rainbow trout, together with 25 million cod (Jensen et al. 2010, 71). ${ }^{23}$ As these figures hint, cod are the very devil to keep in. If they find a hole in the net then through it they go in large numbers. Salmon are more tractable, and large-scale salmon escapes are usually due to error or serious equipment failure. Even so around 200,000 currently get away each year. The figure is large, but it's less than one in a hundred $(0.065 \%)$ that make it out of the farm into the sea.

So the salmon are penned in for economic and environmental reasons. Wild salmon need to be protected. Why? One answer is that anglers want to catch wild, not domesticated, salmon. Indeed, they have field guides to help them distinguish between them. One of these warns that farmed salmon have bodies that are chubbier, tails that are narrower and shorter, damaged gill covers, and fins are worn and uneven (Norsk 2011). The crisis is that the populations of wild salmon have been falling for three decades (Liu et al. 2011a). Biologists say that salmon farming isn't the only reason but it's important even so: ${ }^{24}$

The major negative environmental and biological effects associated with salmon aquaculture on wild salmon include disease and parasite transfer and spread, particularly sea-lice infestation and interbreeding (Liu et al. 2011b).

\footnotetext{
${ }^{23}$ The total salmon production in 2010 was around a million tons, and the value of sales in 2009 was nearly NoK 20 million (Liu et al. 2011a, b, 3).

24 "The decline in fish abundance is caused by a combination of factors associated with human activities including overexploitation, habitat destruction, salmon aquaculture and as well as changes in the natural environment." (Liu et al. 2011b, 414).
} 
They add that between $14 \%$ and $36 \%$ of the breeding salmon in Norway's rivers have come from farms (Liu et al. 2011a, b 3), and that this is leading to loss of genetic diversity, "depression in the fitness and productivity of wild salmon" (Liu et al. 2011a, b, 415), and the possibility that poorly adapted escaped salmon will displace wild salmon because they mature more quickly. Indeed, though this classification is contested (Lien and Law 2011), Atlantic farmed salmon have been officially declared an alien species in the Norwegian Black List (Gederaas 2007). So all of this is a good reason for keeping farmed salmon in their cages. And then there is the problem of parasites, including gyrodactylus and sea-lice. Hence the lice counts, the delousing, the leppefisk, and the deltamethrin, together with other measures that include coordinated louse control on all the farms (it's important that the lice levels should be low when the wild salmon go out to sea), and the decision that some fjords should be temporarily cleared of all farmed salmon at certain times of year.

All in all, when you add it all together, the relations between salmon farming and wild salmon count as a hot political topic. Contested and controversial.

\section{Working on the World}

Vicky: All this is fascinating. But I thought you were going to talk about nature and power.

John: The context is nature, culture and how these relate. In several different places: the farm, environmental science, and Norwegian state policy. One part of the story says that the distinction between "villaks" and "oppdrettlaks" (reared salmon) doesn't really work. There are the escapes and the interbreeding. And we're only 40 years into salmon farming anyway. The great-great-great-great-great-great grandparents of the salmon swimming in the pens were fished out of Norwegian rivers.

Vicky: But they're different too.

John: Yes. They grow a whole lot faster, they resist disease better, and they probably mature sexually more quickly.

Vicky: So interbreeding may not be such a great idea. Rivers and fishermen together with the tourist industry, need artful salmon, not greedy salmon.

John: Agreed. Recreational fishing in Norway is an important industry in its own right. ${ }^{25}$ But let's keep a sense of proportion. The differences between the salmon aren't that large. After all, they are quite happy to interbreed. And the wild salmon aren't very wild anyway. Salmon have been captured and reared and released into rivers for at least 150 years in Norway. The gene pools of the salmon in the rivers have been thoroughly mixed up. And in the longer run people and salmon have been interacting in Norway for a thousand years or more, what with all that hunting and fishing. Whatever a wild salmon is, it's certainly not something that is untouched by human activity.

Vicky: But the divide between nature and culture is still important, isn't it? Indeed your stories suggest that the wild salmon/farmed salmon division informs almost everything that has to do with salmon and people.

John: Yes. That's right. The genetics, the fish behavior studies, the politics of the environment, the licensing systems, the sea-lice policies, the counting, the leppefisk, the deltamethrin, the walls, the nets, the grills, the visits by the vets, not to mention that fact that people like Freddy break their backs hauling in nets

${ }^{25}$ It is estimated that 80,000 Norwegian adults and 35,000 non-Norwegians enjoy sports fishing. (Liu et al. 2011a, b \#3665, 413). 
and dousing fish with chemicals. The division is being done. And done again. And done again.

Vicky: So a nature/culture division makes no sense. At the same time it is absolutely basic. We're being reminded that a foundational nature/culture division that isn't actually foundational is a source of power. It energizes relations. It sets them to work making divisions. It multiplies the versions of those divisions. It creates an imaginary, that of nature untouched. Except that nature untouched is always touched.

John: That's right.

Vicky: But surely we can extract the same lesson from geography, anthropology, sociology or feminism. Indeed I suspect that ANT learned it from feminist writers like Donna Haraway. Think of her Primate Visions. ${ }^{26}$ So what if anything is special about ANT here?

John: Perhaps not so much. But maybe an ANT sensibility brings two things to the party. One we've rehearsed already. It is very, very, sensitive to the heterogeneity of webby relations. It follows the nets, the tools, the work, the crafting and the technoscientific practices. It's very good on materials. And it's almost obsessive in its interest in specificity, in how it is divisions get made. Nature is being divided from culture in Freddy's backache, Knut's fishing, plastic bottles of insecticide, tables of statistics, visits by the vet, and a million more practices. It's into how things get done. Vicky: Which means that it's slow. Care-full. In very particular ways and contexts. For, remember, you made a choice to look at nature rather than gender.

John: Yes.

Vicky: But you said ANT brings two things to the party. What's the second?

John: It's the way this obsession with particular forms of specificity leads on to multiplicity. All the ways these imperfect divides are being done. Because, at the same time, nothing really holds very well, does it? Fish escape. Parasites are washed to and fro. Fish bred on farms end up mixing their genes with those that weren't. Laws are enacted, obeyed, but don't quite stick. Not all the time. But, here's the point, the failures are particular. This time the division failed. Or maybe it didn't. Certainly no salmon were escaping from Sjølaks. But if it did, then there's a next time, and a next time, and a next time. No particular failure undoes the divide. No particular success secures it for more than a moment. It merely strengthens it. Or the need for it. Next time.

Vicky: So?

John: Nature and culture are implicated in one another. Feminism knows this well. Marianne Lien wrestles with it in her anthropology when she writes about biomigration and locality. ${ }^{27}$ And cultural studies goes there too. But if ANT has something to add, then perhaps it is its obsession with multiplicity, all these multiple versions of nature and culture. In practice.

Vicky: Okay. Now I agree with you. And, this obsession with multiplicity exposes a potent source of power while also showing that power is not a monolithic structure. It's not even the effect of a monolithic structure. Instead, through an ANT sensibility to multiplicity, power emerges as an effect of masses of little overlapping and variably successful practices. We can get this out of Foucault. Or Butler. ${ }^{28}$ But what we also learn is that these practices aren't very coherent either. And this is crucial. Because it means that if one fails, it doesn't undermine all the others. A hole in the net doesn't

\footnotetext{
${ }^{26}$ Haraway (1989).

${ }^{27}$ Lien and Davison (2010); Abram and Lien (2011).

${ }^{28}$ Foucault (1979); Butler (1993).
} 
undo the nature/culture divide. It reinforces the urgency of it next time round. The insight is that non-coherence is a source of power. ${ }^{29}$

John: Which is how it is for the impossible division between nature and culture. Impossible. Multiple. Not very successful. Endlessly variable. And endlessly re-energized.

\section{ANT and Politics}

ANT does its theoretical work in its case studies. We started by saying this, and in this piece we have tried to exemplify this. Then again, ANT is grounded. At its best it is a set of sensibilities to the materialities, the relations and the specificities of the world, sensibilities that explore how matters get assembled more or less precariously for a moment. As a part of this it likes to work slowly. It shies away from abstractions and it works care-fully. It is passionate because it follows the trouble, which also means that it tends to undo the obvious. It is sensitive to ethnographic surprises. And while it is working in the world to describe it, it is also working on the world. For descriptions in social science don't just describe. They describe in particular ways. This means that they are performative, that they license particular ways of seeing or frameworks, whilst rendering other less visible and less sustainable.

One consequence of this is that people writing in ANT tend to be skeptical about social structures as these are conventionally described. This is not because the latter don't exist, but because in sociological writing they tend to expand to occupy too much explanatory and political space. We've rehearsed this briefly above, but the general point is that ANT tends to avoid simple reductionisms. To put it differently, ANT tends to assume that the whole world may be discovered within any specific scene or set of practices. The issue, then, is what kind of context to create. Or contexts?

In this piece our major object has been to show how ANT might work in practice. There are, as is obvious, many stories that might be told about fish farming in Norway. In other intellectual locations members of the project including Marianne Lien and Gro Ween have made quite different contexts by telling quite different stories. ${ }^{30}$ Here, however, we have explored how the division between nature and culture might be informed by looking at the distinction between wild salmon, villaks, and farmed salmon or oppdrettlaks. Since the nature/culture binary is deeply embedded in Western theory and practice, we hope that this will have been of interest to readers. But we have also made a more theoretical point. We have argued that power (together with the large scale structural asymmetries usually said to go with power) is achieved in multiple practices and that those practices are neither very successful nor particularly coherent.

Our hope is that this may count as a small example of how ANT does its theoretical work: that is, through carefully articulated case studies. As is obvious, a case study of the kind we have organized here is scarcely naive. It is not a simple description (assuming that such a thing were possible which it is not). It does not simply work in the world. It also works on it. So it is theorized, except that we have also argued that in ANT, theory is not a set of rules or prescriptions. It isn't even a collection of general principles. Rather we have suggested that it is best treated as a sensibility to features of the world that aren't quite those of standard social science - to the heterogeneous materials, relations and uncertainties of the practices that compose the world. And, as we have also tried to show, this is a sensibility that has political consequences. It is something like this. To the extent that ANT explores the contingencies of power it also generates tools for undoing the inevitability of that power. More strongly, it starts on the process of undoing its inevitability. For, at its best, ANT works on the

\footnotetext{
${ }^{29}$ See Latour $(1988,202-3)$ for a parable that makes this argument.

${ }^{30}$ For Lien and Law (2011) the context is domestication; for Ween (2012) and Ween and Lien (2012) it is indigeneity; for Law and Lien (2013) it is the textures of interaction.
} 
assumption that other worlds are possible. Then it goes looking for them, and tries to articulate them. And since there are different practices and they aren't particularly coherent, putting their non-coherences together is a resource for making a difference. The hope is this: If we can craft appropriate tools for articulation it will be possible to know and make space for different and better social arrangements (for this argument developed differently see Singleton and Law 2013).

\section{References}

Abram, Simone, and Marianne Elisabeth Lien. 2011. Performing nature at world's ends. Ethnos 76(1): 3-18. Amundsen, Bård, Jakobsen Siw Ellen, and Lie Else. 2010. New approach to combating sea lice: Wrasse to the rescue. Oslo: Norges forskningsråd: The Research Council of Norway. Accessed 25 July 2012. http:// www.forskningsradet.no/en/Newsarticle/Wrasse_to_the_rescue/1253955126725?WT.mc_id=alphagalileo.

Asdal, Kristin, and Ingunn Moser. 2012. Experiments in context and contexting. Science, Technology \& Human Values 37(4): 291-306.

Butler, Judith. 1993. Bodies that matter: On the discursive limits of "Sex". New York and London: Routledge.

Callon, Michel. 1986. Some elements of a sociology of translation: Domestication of the scallops and the fishermen of Saint Brieuc Bay. In Power, action and belief: A new sociology of knowledge? Sociological review monograph, ed. John Law, 196-233. London: Routledge and Kegan Paul.

Deady, Sandra, Sarah J.A. Varian, and Julie M. Fives. 1995. The use of cleaner-fish to control sea lice on two Irish salmon (Salmo salar) farms with particular reference to wrasse behaviour in salmon cages. Aquaculture 131(1-2): 73-90.

Foucault, Michel. 1979. Discipline and punish: The birth of the prison. Harmondsworth: Penguin.

Gederaas, Lisbeth, Ingrid Salvesen, and Åslaug Viken (eds.). 2007. 2007 Norwegian Black List: Ecological Risk Analysis of Alien Species. Trondheim: Norwegian Biodiversity Information Centre. Also available at http://www.artsdatabanken.no/Norsksvarteliste2007_LXfSH.pdf.file.

Haraway, Donna J. 1989. Primate visions: Gender, race and nature in the world of modern science. London: Routledge and Chapman Hall.

Haraway, Donna J. (ed.). 1991. Situated knowledges: The science question in feminism and the privilege of partial perspective. In Simians, cyborgs and women: The reinvention of nature, 183-201 in Donna Haraway. London: Free Association Books. Also available at http://www.staff.amu.edu.pl/ ewa/ Haraway,\%20Situated\%20Knowledges.pdf.

Haraway, Donna J. 1994. A game of cats cradle: Science studies, feminist theory, cultural studies. Configurations 1: 59-71.

Haraway, Donna J. 1996. Modest witness: Feminist diffractions in science studies. In The disunity of the sciences: Boundaries, contexts, and power, ed. Peter Galison and David J. Stamp, 428-441. Stanford, California: Stanford University Press.

Haraway, Done J. (ed.). 2010. When species meet: Staying with the trouble. Environment and Planning D: Society and Space 28(1): 53-55. Also available at http://www.envplan.com/abstract.cgi?id=d2706wsh.

Ingold, Tim. 2011. Being alive: Essays on movement, knowledge ad description. Abingdon and New York: Routledge.

Jensen, Ø., et al. 2010. Escapes of fishes from Norwegian sea-cage aquaculture: Causes, consequences and prevention. Agriculture Environment Interactions 1: 71-83.

Kuhn, Thomas S. 1970. The structure of scientific revolutions. Chicago: Chicago University Press.

Latour, Bruno. 1987. Science in action: How to follow scientists and engineers through society. Milton Keynes: Open University Press.

Latour, Bruno. 1988. Irréductions, published with The Pasteurisation of France. Cambridge Mass.: Harvard. Latour, Bruno. 2010. An attempt at a "Compositionist Manifesto". New Literary History 41(3): 471-490.

Lave, Jean. 2011. Apprenticeship in critical ethnographic practice. Chicago: Chicago University Press.

Law, John. 1986. On the methods of long distance control: Vessels, navigation and the portuguese route to India. In Power, action and belief: A new sociology of knowledge? Sociological review monograph, ed. John Law, 234-263. London: Routledge and Kegan Paul.

Law, John. 2004. After method: Mess in social science research. London: Routledge.

Law, John. 2008. Actor-network theory and material semiotics. In The New Blackwell companion to social theory, 3rd ed, ed. Bryan S. Turner, 141-158. Oxford: Blackwell. 
Law, John, and Marianne Elisabeth Lien. 2013. Slippery: Field notes on empirical ontology. Social Studies of Science 43(3): 363-378. Also available at http://www.sv.uio.no/sai/english/research/projects/newcomers/ publications/working-papers-web/Slippery\%20revised\%2013\%20WP\%20version.pdf.

Lien, Marianne E., and Aidan Davison. 2010. Roots, rupture and remembrance: The Tasmanian lives of Monterey pine. Journal of Material Culture 15(2): 1-21.

Lien, Marianne Elisabeth, and John Law. 2011. "Emergent Aliens": On salmon, nature and their enactment. Ethnos 76(1): 65-87. Also available at http://www.sv.uio.no/sai/english/research/projects/newcomers/ publications/working-papers-web/Emergent\%20aliens\%20Ethnos\%20revised\%20WP\%20version.pdf.

Liu, Yajie, et al. 2011a. An ecological-economic model on the effects of interactions between escaped farmed and wild salmon (Salmo salar). Trondheim: Norwegian University of Science and Technology.

Liu, Yajie, Jon Olaf Olaussen, and Anders Skonhoft. 2011b. Wild and farmed salmon in Norway-A review. Marine Policy 35(3): 413-418.

Mattilsynet: Norwegian Food Safety Authority. 2012a. About The Norwegian Food Safety Authority. Oslo: Mittilsynet: Norwegian Food Safety Authority. Accessed 25 July 2010. 2012http://www.mattilsynet.no/ english/about.

Mattilsynet: Norwegian Food Safety Authority. 2012b. Lakselus - spørsmål og svar. Oslo: Mittilsynet: Norwegian Food Safety Authority. http://www.mattilsynet.no/fisk/smittevern_og_bekjempelse/lakselus/ arkiv/lakselus_sp_rsm_1_og_svar_80943. Accessed 25 July 2012.

Mol, Annemarie. 2008. The logic of care: Health and the problem of patient choice. London: Routledge.

Mol, Annemarie, Ingunn Moser, and Jeannette Pols (eds.). 2010. Care in practice: On tinkering in clinics, homes and farms. Bielefeld: Transcript Publishers.

Norsk, Lakselver. 2011. Norsk Lakselver Guide til Villaks-Gjenkjenning. Oslo: Norsk Lakselver.

Revie, Crawford, et al. 2009. Sea Lice working group report. Trondheim: Norwegian Institute for Nature Research. Also available at http://www.nina.no/archive/nina/PppBasePdf/temahefte/039.pdf.

Rock, Paul. 1979. The making of symbolic interactionism. London: Macmillan.

Singleton, Vicky, and John Law. 2013. Devices as Rituals 6(3): 259-277. Also available at http://www. heterogeneities.net/publications/SingletonLaw2012DevicesAsRituals.pdf.

Stengers, Isabelle. 2011. "Another science is possible!" A plea for slow science. Brussels: Université Libre de Brussels. Also available at http://threerottenpotatoes.files.wordpress.com/2011/06/stengers2011_pleaslowscience.pdf.

Thompson, Charis. 2007. Making parents: The ontological choreography of reproductive technologies. Cambridge, Mass.: MIT.

Ween, Gro. 2012. Performing indigeneity in human-salmon relations. Salmon, sami and natural resource management. In Eco-global crimes: Contemporary and future challenges, ed. Ellefsen Rune, Sollund Ragnhuld, and Larsen Guri. London: Ashgate.

Ween, Gro, and Marianne E. Lien. 2012. Decolonialization in the Arctic? Nature practices and land rights in the Norwegian High North. Journal of Rural and Community Development 7(1): 93-109.

John Law is Professor of Sociology at the Open University, and a Director of the Centre for Research on Socio-cultural Change (CRESC) where he directs the Social Life of Method theme. Trained in STS and Sociology, he has contributed to the development of actor network theory and its more fluid and politically literate successor projects. Currently he is working with anthropologist Marianne Lien on nature and culture, with a particular focus is an ethnographic study of salmon farming; with collaborators including Vicky Singleton and Annemarie Mol on material-semiotic methods and politics, using materials from empirical work on farming and health care; with Wen-yuan Lin on post-colonial knowledge spaces and ontological politics, including alternative Chinese modes of knowing; and with Karel Williams and his co-workers on elite politics and the framing of UK policies. He is the author of numerous journal articles and book chapters, and of After Method: Mess in Social Science Research. His personal web page is http://www.heterogeneities.net/.

Vicky Singleton is a Senior Lecturer in The Centre for Science Studies and The Centre for Gender and Women's Studies, Department of Sociology, Lancaster University, UK. She carries out ethnographic case studies on care and the enactment of policies in two main areas; the first, public health and biomedicine and the second, farming. Case studies have included the UK Cattle Tracing System, acute care of patients with Alcoholic Liver Disease, the UK Cervical Screening Program and an initiative to train members of a rural community in Cardio-Pulmonary Resuscitation. Her work has been published as book chapters and journal articles including in Social Studies of Science, Science, Technology and Human Values, Environment and Planning D: Society and Space and Organization. She is currently writing a book about Care in and for Policy. 